\title{
Instant coffee with steamed PVA beans: Physical-chemical and sensory aspects
}

\author{
Café solúvel produzido com grãos pva tratados com vapor: \\ Aspectos físico-químicos e sensoriais
}

\author{
Tamiris Aparecida Diniz dos Reis ${ }^{1}$ (D), Antonio José de Conti ${ }^{2}$ (D), Eliseo Alexander López Barrientos ${ }^{3}$ (D), \\ André Luiz Buzzo Mori' ${ }^{(D)}$, Marta de Toledo Benassi ${ }^{1 *}$ (D)
}

\author{
${ }^{1}$ Universidade Estadual de Londrina/UEL, Departamento de Ciência e Tecnologia de Alimentos, Londrina, PR, Brasil \\ ${ }^{2}$ Cia Iguaçu de Café Solúvel, Pesquisa e Desenvolvimento, Cornélio Procópio, PR, Brasil \\ 3Universidade Zamorano, Departamento de Agroindústria Alimentaria, San Antonio de Oriente, FM, Honduras \\ *Corresponding author: martatb@uel.br \\ Received in October 30, 2019 and approved in December 19, 2019
}

\begin{abstract}
Around $20 \%$ of Brazilian coffee production corresponds to defective beans (PVA), which decreases the quality of the coffee brews. Steam treatment has been reported as an alternative to improve the cup quality of coffee products. This research aimed to study the feasibility of using steamed Robusta PVA beans in instant coffee products. After the steam treatment ( 2 bar for 3 min), the Robusta PVA was dried, roasted, subjected to extraction in a pilot plant, and freeze-dried. The steamed and untreated Robusta PVA materials (raw, roasted, and instant coffees) and blends of instant Arabica coffee with PVA were characterized. The steamed Robusta PVA instant coffee presented $7.01 \mathrm{~g}$ caffeine and $8.74 \mathrm{~g}$ total chlorogenic acids in $100 \mathrm{~g}$ product. Instant coffee blends with $30 \%$ and $50 \%$ of steamed Robusta PVA in Arabica coffee were studied. A sensory difference between blends with steamed and untreated Robusta PVA was only perceived by the addition of $50 \%$ PVA. The blend with $50 \%$ of steamed coffee was preferred and well accepted (average grade of 7.9 on a 10 -scale). The use of steamed Robusta PVA coffee (under mild steam treatment conditions, 2 bar/3 min) in instant coffee was viable, and it was obtained an instant coffee to be used in a blend with $50 \%$ of Arabica coffee with a good profile of bioactive compounds and sensory acceptance.
\end{abstract}

Index terms: Coffea canephora; defects; blends; bioactive compounds; steam treatment.

\begin{abstract}
RESUMO
Em torno de 20\% da produção brasileira de café corresponde a grãos defeituosos (PVA), que reduzem a qualidade das bebidas. O tratamento com vapor tem sido proposto como alternativa para melhorar a qualidade de produtos de café. $\mathrm{O}$ trabalho teve como objetivo estudar a viabilidade do emprego de grãos defeituosos (PVA) de café Robusta tratados com vapor em produtos de café solúvel. Após o tratamento com vapor (pressão de 2 bar por 3 min), os grãos Robusta PVA foram secos, torrados, extraídos em planta piloto e liofilizados. Os materiais Robusta PVA tratados com vapor e não tratados (café cru, torrado e solúvel) e os blends de cafés solúveis produzidos com café Arábica foram caracterizados. O café solúvel Robusta PVA tratado com vapor apresentou 7,01 g de cafeína e 8,74 g de ácidos clorogênicos totais em 100 g de produto. Foram estudados blends de café solúvel com 30\% e 50\% de Robusta PVA tratado com vapor com café Arábica. Diferença sensorial entre os blends com Robusta PVA tratado e não tratado foi percebida somente com a adição de 50\% de PVA. O blend com $50 \%$ de café tratado com vapor foi preferido e bem aceito (nota média de 7,9 em escala de 10). O uso de café Robusta PVA tratado com vapor (sob condições brandas de tratamento, 2 bar/3 min) em café solúvel foi viável, sendo possível obter café solúvel para ser usado em um blend com $50 \%$ de café Arábica com um bom perfil de compostos bioativos e aceitação sensorial.
\end{abstract}

Termos para indexação: Coffea canephora; defeitos; blends; compostos bioativos; tratamento com vapor.

\section{INTRODUCTION}

Brazil is the world's largest producer and exporter of coffee, producing the two main economically relevant species, Coffea arabica (Arabica coffee) and Coffea canephora (Robusta coffee). In this year, Brazil exported over 30.7 million bags of $60 \mathrm{~kg}$ of coffee products, of which
3.7 million were of instant coffee (Cecafé, 2019). Robusta coffee has a higher content of caffeine and soluble solids. It is used in roasted and ground coffee products in blends with Arabica coffee to obtain a stronger coffee brew; it is also the main raw material for instant coffee production (Lingle; Menon, 2017). 
REIS, T. A. D. dos et al.

Among the intrinsic defects of coffee, the black, green (immature or unripe) and sour beans, commonly called as PVA, from the Portuguese "preto", "verde", and "ardido", are the ones that affect the most the cup quality. Black beans are due to microbial fermentation when over-ripening fruits that fall during harvest remain in the soil; sour beans occur due to lack of water during fruit development or abnormal fermentation of coffee beans. These two defects are associated with acid taste. Green beans, from harvesting immature fruits, can lead to astringency, and bitter or metallic flavor (Bandeira et al., 2009; Bee et al., 2005; Toci; Farah, 2014).

Typically, Brazil uses harvesting techniques such as stripping and mechanical harvesting, therefore in addition to ripe fruits (cherry), immature and over-ripened fruits are also harvested all at once. After grading, these defective beans, which are unsuitable for export, are usually incorporated into products for the internal market. Approximately $20 \%$ of all Brazil's coffee production is defective beans (Bandeira et al., 2009; Craig et al., 2015; Oliveira et al., 2006), but, despite the large volume produced, this material has been little studied.

Health benefits related to moderate and regular coffee consumption have already been described, including positive cognitive and memory effects and reductions in blood sugar levels as well as anti-inflammatory, neuroprotective and cytoprotective benefits (Amer; Mazen; Mohamed, 2017; Bedoya-Ramírez et al., 2017; Martini et al., 2016; Yoshinari; Igarashi, 2015). Several compounds associated with the sensory characteristics of coffee brews - such as caffeine and chlorogenic acids - also stand out as bioactive, and their contents in coffee products may be affected by the presence of defective beans. Higher content of chlorogenic acids and caffeine were reported in PVA beans (Franca; Mendonça; Oliveira, 2005; Ramalakshmi; Kubra; Rao, 2007).

Some patents recommend steam treatment of raw Robusta coffee beans as an alternative to improve brew quality (Becker; Schlabs; Weisemann, 1991; Varsányi et al., 1988). In previous studies, our research group observed that the steam treatment improved the profile of volatile compounds in the Robusta PVA roasted coffee (Kalschne et al., 2018), maintaining good retention of bioactive compounds (Kalschne et al., 2019). The authors reported that it was possible to obtain roasted coffee brews with good acceptance, adding up to $30 \%$ of steamed PVA coffee in a blend with Arabica coffee (Kalschne et al., 2018); however, there is no information on the use of PVA for instant coffee. Based on this, this study aimed to study the feasibility of using steamed Robusta PVA coffee in instant coffees. The composition of all Robusta PVA materials and blends (instant Arabica coffee with Robusta PVA) were studied. The sensory perception of the presence of the steamed defect and the acceptance of the brews were also evaluated.

\section{MATERIAL AND METHODS}

\section{PVA coffees preparation, steam-treatment description, and production of instant coffee}

Companhia Iguaçu de Café Solúvel (Cornélio Procópio, Brazil) produced and provided all the necessary material for this study.

Coffea canephora grown in the state of Espírito Santo (Brazil), from the 2016/2017 crop, was used to obtain the defective beans. The separation and classification of the material were done in the industry by trained employees. The raw Robusta beans were separated by a Giga Mode G10000 industrial optical electronic selector (Bühler Sanmak Ltda, Blumenau, Brazil) until about $71 \mathrm{~kg}$ of rejected beans were obtained. The rejected material was characterized by visual assessment as $50.1 \%$ PVA beans $(17.2 \%$ black beans, $12.1 \%$ green beans and $20.8 \%$ sour beans), $25.2 \%$ of other defects and impurities (shell/broken, insect-damaged, husk, dried cherry, stick, stone, and floater) and $24.7 \%$ of non-defective beans.

Half of the material was used for steam treatment (ST). The raw Robusta beans $(38 \mathrm{~kg})$ were submitted to treatment in an equipment developed by Companhia Iguaçu de Café Solúvel as described by Kalschne et al. (2018) each time batches of $3 \mathrm{~kg}$ were steamed.

The equipment consists of a cylindrical container made of stainless steel AISI standard, with holes of $3.0 \mathrm{~mm}$ in diameter in the surface, resulting in a $20 \%$ area opened for steam passage. The container is $1200 \mathrm{~mm}$ high, with an external diameter of $50.8 \mathrm{~mm}$ and a wall thickness of 1.5 mm, with SMS type thread connections at the ends. The pipe was placed inside a pressure vessel, and the steam was injected from a biomass boiler. The pressure was adjusted through a controlling valve installed in the steam pipe, and a digital manometer recorded the applied pressure. Treatment conditions (pressure of 2 bar and 3 min time) was defined based on previous studies, which indicated a product with an adequate profile of volatile compounds (Kalschne et al., 2018) and with good retention of bioactive compounds (Kalschne et al., 2019).

After the treatment, the steamed Robusta samples (initial moisture ranging from 29 to $37 \%$ ) were dried in 
batches in a TECNAL TE-394/2 oven (Piracicaba, Brazil), at temperatures ranging from 60 to $70{ }^{\circ} \mathrm{C}$. After drying, final beans moisture ranged from 10 to $12 \%$, and about $33 \mathrm{~kg}$ of product (steamed unroasted/raw Robusta PVA coffee, SUD) was obtained.

Another part of the material $(33 \mathrm{~kg}$, average moisture of $9.2 \%$ ) was kept untreated to be used as a control (untreated unroasted/raw Robusta PVA coffee, UUD).

Moisture determinations were made on the ground beans (description in item 2.2) to characterize the material and follow the drying process.

The dry beans were medium roasted in a Lilla model OPUS 2 industrial roaster (Guarulhos, Brazil), for small capacities (up to $24 \mathrm{~kg}$ per batch). The roasting process of the SUD and UUD coffees was done in batches, with around $11 \mathrm{~kg}$, so 3 batches for each type of coffee were processed. In order to standardize the color of the roasted coffees, different process conditions were applied, depending on the material. Temperatures in the range of 210 to $214{ }^{\circ} \mathrm{C}$ (temperature at the end of the roast) and process time from 11 to 16 min were applied for roasting UUD coffees. For SUD coffees, which were already subjected to preliminary heat treatments (steaming and drying), less aggressive roasting conditions were used: temperatures from 204 to $206{ }^{\circ} \mathrm{C}$ and times of 11 to 19 min. For the characterization of the roast degree, color determination was made for the roasted and ground coffees (description in item 2.2). Both steamed and untreated roasted PVA Robusta coffee (SUD and UUD) were also characterized by moisture.

The production of instant coffees from roasted beans was carried out in an industrial pilot plant, being carried out in batches of $30 \mathrm{~kg}$ for each type of coffee, steamed (SRD) and untreated (URD) Robusta. The roasted beans were granulated and subjected to percolation extraction. Water under pressure at $180^{\circ} \mathrm{C}$ was fed into the first percolation stage (oldest coffee) and percolated in the following stages, until in the last stage (sixth column), the extract reaches the freshly-charged coffee. During the process, the amount of soluble solids in the extract increased, while the temperature decreased, so the last column containing fresh coffee is extracted at approximately $100^{\circ} \mathrm{C}$ to minimize thermal damage and favoring the preservation of aroma and flavor. Extracts drying was done by a freeze-drying process, obtaining about $0.8 \mathrm{~kg}$ of each instant coffee, produced from steamed and untreated Robusta PVA, leading to a steamed instant Robusta PVA coffee (SID) and an untreated instant Robusta PVA coffee (UID), respectively.
Since the product was intended for blends, we studied the proportions previously reported by our research group for roasted coffee blends (Kalschne et al., 2018). An instant freeze-dried Arabica coffee (AC) was produced under similar process conditions. The instant Arabica coffee was used in the composition of instant coffee blends with proportions of $30 \%$ and $50 \%$ of SID and UID, denominated SID $30 / A C$, SID $50 /$ $\mathrm{AC}$, UID30/AC, and UID50/AC, respectively. Instant coffees were also characterized regarding color and moisture.

\section{Physical-chemical characterization of materials and instant coffees}

The studied Robusta materials, raw (SUD and UUD), and roasted PVA (SRD and URD), as well as the instant coffees produced (SID, UID, and AC), were characterized by color and moisture, as reported previously.

Moisture measurements were done in genuine duplicates $(2 \mathrm{~g})$ using the infrared equipment OHAUSMB45 (Parsippany, USA) at $105{ }^{\circ} \mathrm{C}$ for $7 \mathrm{~min}$. The raw and roasted beans (SUD, UUD, SRD, and URD) were ground in an IKA A11BS32 mill (Staufen, Germany) to obtain standardized particles of 28 mesh $(600 \mathrm{~mm})$. The standardization of particle size was done in a Bertel sieve (Caieiras, Brazil). Instant coffees (SID, UID, and AC) were analyzed directly. Moisture data were used to express the contents of the chemical constituents on a dry basis (db).

Color determinations were done in genuine duplicate, using a portable colorimeter KONICA MinoltaCR400 (Osaka, Japan), with 45/0 geometry and D65 illuminant. Raw and roasted beans were analyzed in ground form, and instant coffees, directly.

For the analysis of the bioactive compounds in raw coffees, extraction was carried out based on Kitzberger et al. (2013). Samples $(0.50 \mathrm{~g})$ were extracted with $50 \mathrm{~mL}$ of boiling water, for $45 \mathrm{~min}$. As for roasted coffees, the same amount of sample was used, with extraction in 30 $\mathrm{mL}$ of water at $80^{\circ} \mathrm{C}$ for $10 \mathrm{~min}$ (Kalschne et al., 2019). After extraction (in genuine duplicate), the extracts were filtered in a $100 \mathrm{~mL}$ volumetric flask. Instant coffees $(0.2 \mathrm{~g})$ were diluted $(100 \mathrm{~mL})$ and a proper aliquot was transferred to a $25 \mathrm{~mL}$ volumetric flask; the volume was filled with water. Different extraction methods were applied in order to obtain an efficient extraction for each matrix.

Caffeine and total chlorogenic acids (CGA) determination was based on Corso, Vignoli and Benassi (2016). An HPLC Shimadzu (Kyoto, Japan) with two 
REIS, T. A. D. dos et al.

pumps LC-10AD, Rheodyne injector valve $(20 \mu \mathrm{L})$, and UV/visible SPD-10A detector was used. The following materials were employed: HPLC grade acetonitrile (SigmaAldrich, St. Louis, USA), acetic acid (purity $\geq 99.8 \%$, J.T Baker, Mexico); $0.22 \mu \mathrm{m}$ syringe filter Millex-GV PVDF (Millipore, Brazil); and standards of 5-caffeoylquinic acid (5-ACQ) and caffeine (Sigma, St. Louis, USA). The water was obtained from the Purelab Option-Q system (Elga, High Wycombe, USA). A Spherisorb ODS1 column (150 x $4.6 \mathrm{~mm}, 3 \mu \mathrm{m})$ (Waters, Ireland) was used. The compounds were eluted with aqueous solution of acetic acid $5 \%$ (A) and acetonitrile (B) at a flow rate of $0.5 \mathrm{ml} \mathrm{min}^{-1}$ using the following gradient: $0-10 \mathrm{~min}: 5 \% \mathrm{~B}$; $10-25 \mathrm{~min}: 13 \% \mathrm{~B}$; 25-35 min: 5\% B. Detection was set at $272 \mathrm{~nm}$ for caffeine and $320 \mathrm{~nm}$ for CGA. Quantification was carried out by external standardization, using 5-point curves (in triplicate) in the range of 1 to $31 \mu \mathrm{g} \mathrm{mL}^{-1}$ for 5-ACQ and 5 to $40 \mu \mathrm{g}$ $\mathrm{mL}^{-1}$ for caffeine. Total CGA content was estimated by the sum of the compounds detected at $320 \mathrm{~nm}$, using 5-ACQ as a standard (Corso; Vignoli; Benassi, 2016). Analyses were carried out in genuine duplicate, results were expressed in $\mathrm{g} 100 \mathrm{~g}^{-1} \mathrm{db}$.

Results were evaluated by the t-test ( $\leq 0.05)$, using the Statistica 7 program (Statsoft, 2006).

\section{Sensory analysis}

Analyses were performed at the Sensory Analysis Laboratory, in individual cabins, under white light. The study was authorized by the Ethics Committee of Universidade Estadual de Londrina (CEEP no 68561817.9.0000.5231). Coffee consumers, among university students, professors, and employees, were recruited.

Brews from the blends - instant Arabica coffee with $30 \%$ or $50 \%$ of steamed and untreated instant Robusta defects (SID30/AC, SID50/AC, UID30/AC, and UID50/ AC) - were prepared according to Kobayashi and Benassi (2012). Instant coffee (1.2 g) was dissolved in $50 \mathrm{~mL}$ mineral water (Ouro Fino, Campo Largo, Brazil) $(\mathrm{pH}=$ 7.60) at $95^{\circ} \mathrm{C}$.

Brews were not sweetened for the triangular and paired preference tests. For the acceptance test, sucrose $(4.75 \mathrm{~g} / 50 \mathrm{~mL})$ was added to the brews, corresponding to $9.5 \%$, estimated as the ideal sweetness for instant coffee brews by Brazilian consumers (Moraes; Bolini, 2010). After preparation, the brews were stored in thermal bottles for a maximum of two hours. The coffee brews were served in $50 \mathrm{~mL}$ styrofoam cups with plastic caps, immediately after analysis, in order to keep the beverages around $70^{\circ} \mathrm{C}$ (Corso; Vignoli; Benassi, 2016).

\section{Evaluation of the difference between blends}

Arabica coffee blends with steamed and untreated Robusta PVA coffee were evaluated by triangular tests. A balanced design was used, and the order of presentation of the samples was randomized across assessors.

The V-Power (2019) program provided by OP\&P Product Research was used to define the minimum number of assessors. Considering the $\alpha=0.05$ and $\beta=0.20$ and discriminator ratio $(\mathrm{Pd})$ of $50 \%$, a minimum of 16 assessors was recommended.

Two sessions were carried out, with a total of 79 assessors (39 and 40 assessors, respectively). The panel was gender-balanced ( $46 \%$ female and $54 \%$ male), young (58\% below 25 years and $35 \%$ between 25 and 40 years old) and with high schooling (54\% complete high school education, $46 \%$ graduates). Most of them were also familiarized with the procedures of sensory analysis ( $76 \%$ ), as they had previous experience as sensory assessors. In general, they were regular coffee consumers: $85 \%$ reported consuming it daily ( 1 to 5 cups per day), and the others consumed it at least once/week. The panel reported consuming roasted $(72 \%)$ and instant coffee $(28 \%)$, similar to the described in an extensive survey of Brazilian coffee consumption trends (Abic, 2014).

The first session compared blends with 30\% PVA coffee (SID30/AC and UID30/AC) the second session blends with 50\% PVA (SID50/AC and UID50/AC).

For data analysis, V-Power (2019) program was also used, considering the same sensibility parameters defined previously.

\section{Preference and acceptance evaluation of blends}

The bilateral paired preference test was performed in lab scale with 40 assessors ( 20 women and 20 men). The panel was young ( $58 \%$ under 25 years and $38 \%$ between 25 and 40 years old), with a high level of education ( $42 \%$ complete high school, and 58\% graduates), experience in sensory analysis $(93 \%)$ and a high frequency of coffee consumption ( $96 \%$ consumed at least 1 cup/day).

Assessors were asked to indicate their preferred sample, comparing the Arabica coffee blends with 50\% PVA coffee (SID50/AC and UID50/AC). Considering the defined sensibility parameters $\left(\alpha=0.05\right.$ and $\left.\mathrm{P}_{\max }=50 \%\right)$, at least 28 assessors were recommended; the preference were also evaluated by the V-Power (2019) program.

Coffee consumers (105 participants, 62 women and 43 men) were recruited to evaluate acceptance. Consumers were young $(58 \%$ below 25 years and $40 \%$ between 25 and 40 years old) and had a diversity of schooling 
(61\% complete high school, and 39\% graduates). They consumed roasted coffee prepared in a traditional way $(62 \%)$ or as capsules $(3 \%)$ or espresso $(0.8 \%)$; followed by instant coffee (34\%), and other types (such as cappuccino). Consumers reported consuming coffee regularly: one to three times/week (8\%), 1 to 2 cups/day (63\%) and more than 3 cups/day (27\%).

Acceptance of the most preferred brew (SID50/ AC) was evaluated using a 10-cm hybrid hedonic scale (Villanueva; Petenate; Silva, 2005). Data was analyzed considering the average grade and percentages of acceptance and rejection.

\section{RESULTS AND DISCUSSION}

\section{Characterization of the composition of raw, roasted and instant coffees}

Figure 1 shows images of raw, roasted and instant (steamed and untreated) Robusta coffees as well as of the instant Arabica coffee used to compose the blends. Color and moisture data were also specified.

For raw PVA coffees (Figure 1), a darker and reddish color was observed for the steamed coffee (SUD) (lower values of lightness and hue), compared to UUD. So, even under the mild ST conditions used ( $2 \mathrm{bar} / 3$ $\mathrm{min}$ ), changes in the bean structure had already initiated. Regarding composition, a higher content of caffeine and total chlorogenic acids was obtained for SUD compared to UUD (Table 1), indicating that the changes in the bean with ST increased the availability of the compounds in the matrix, favoring its extraction and analysis.

A comparison between raw and roasted Robusta PVA beans showed a reduction in moisture, lightness, and hue values. After roasting, a smaller difference in lightness between SRD and URD was noticed (Figure 1), indicating that the roasting standardization for steamed and untreated beans (with a more intense roast for the untreated ones) was efficient. CGA content was reduced with the roasting process (Table 1), justified by the low thermal stability of the compound (Dias; Benassi, 2015).

For Robusta PVA roasted coffees, no differences were observed in CGA contents however, the untreated URD showed higher caffeine content (Table 1). The ST can cause leaching, especially of caffeine, which presents high solubility in water $\left(22 \mathrm{~g} \mathrm{~L}^{-1}\right)$ (NCBI, 2019).

Kalschne et al. (2019) also verified that CGA content was less affected by steaming, while a reduction in caffeine content was observed in roasted Robusta PVA coffees under ST. The authors described that the caffeine

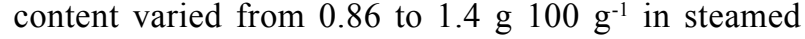
Robusta PVA coffees treated at different conditions (steam pressure from 2 to 8 bar, and process time from 3 to 29 min) compared to $1.70 \mathrm{~g}$ of caffeine in $100 \mathrm{~g}$ in control/ untreated roasted Robusta PVA coffee. A different behavior was observed for the CGA content, which varied on a wide range of values for steamed Robusta PVA coffees (from

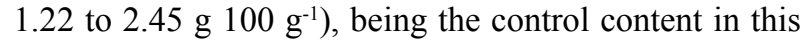

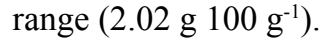

The roasted PVA coffees (URD and SRD) had high

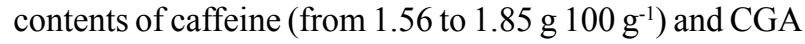

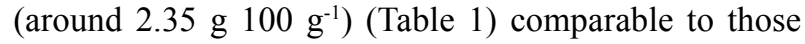
usually described in the literature. Roasted Robusta coffee from different origins and several degrees of roasting showed caffeine contents between 1.56 and $2.55 \mathrm{~g} 100$ $\mathrm{g}^{-1}$ (Daglia et al. 1994; Hečimović et al., 2011; Souza; Benassi, 2012; Dias; Benassi, 2015) and CGA contents

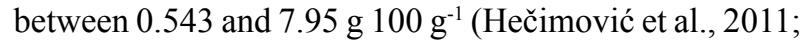
Perrone et al., 2008).

A comparison between roasted and instant Robusta PVA coffees showed a reduction in moisture and hue. After the extraction and drying processes to produce the Robusta instant coffees, SID and UID presented similar moisture and color (Figure 1). Instant coffees had higher bioactive content compared to roasted products due to the removal of the insoluble material during the extraction (Table 1). This effect of relative concentration was higher for caffeine, well known as thermostable compound (Dias; Benassi, 2015).

Robusta instant coffee produced from the untreated product UID presented higher caffeine content than that produced by SID, due to leaching in ST (Table 1). Opposite behavior was observed for CGA content, which was higher in SID, that was due probably to the more intense roasting process used for the untreated product, in addition to a sequence of high-temperature treatments during extraction and drying.

However, despite the introduction of an extra stage in the process, the instant coffee produced from steamed Robusta PVA (SID) had higher contents of caffeine and

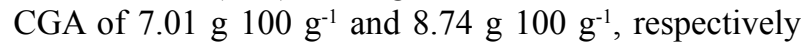
(Table 1) than those usually described in the literature. For caffeine, contents from 1.76 to $5.82{\mathrm{~g} 100 \mathrm{~g}^{-1} \text { were reported }}$ for Robusta instant coffees, with different roasting degrees and extraction processes (Vignoli; Bassoli; Benassi, 2011; Wongsa et al., 2019), and in the range of 2.32 to $4.08 \mathrm{~g}$ $100 \mathrm{~g} \mathrm{~g}^{-1}$ for Brazilian commercial instant coffees (Marcucci et al., 2013). Corso, Vignoli and Benassi (2016) observed

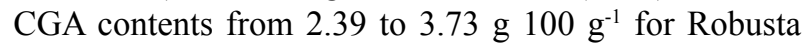
instant coffees with different roasting degrees. 
UNTREATED

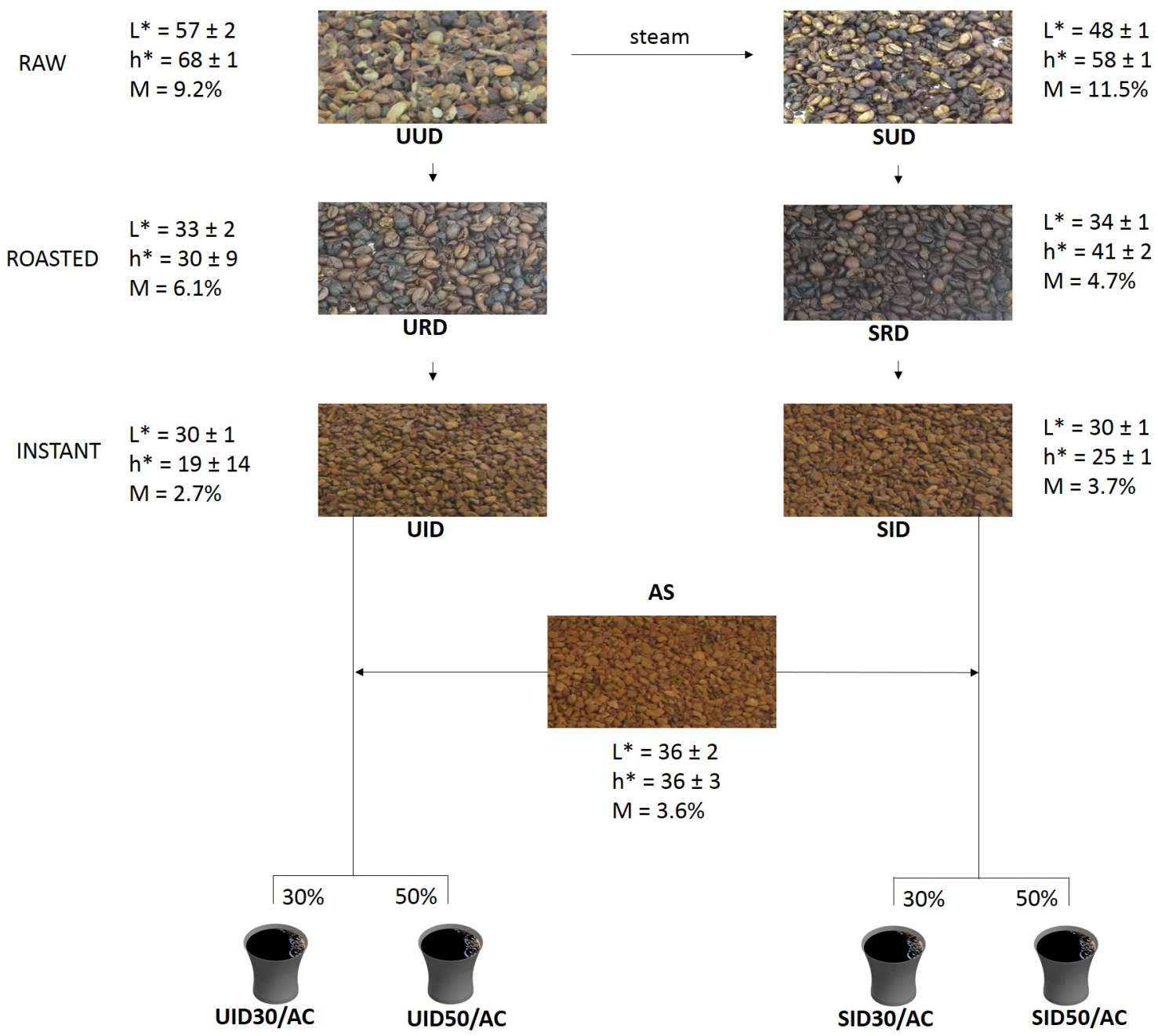

Figure 1: Raw, roasted and instant Robusta PVA coffee (steamed and untreated) and instant 100\% Arabica: images and characteristics of color and moisture.

*Mean \pm standard deviation of genuine duplicates for moisture $(M)$ and color parameters: lightness $\left(L^{\star}\right)$ and hue $(h *)$. Identification of samples - Robusta coffee PVA: UUD: untreated unroasted/raw, SUD: steamed unroasted/raw, URD: untreated roasted, SRD: steamed roasted, UID: untreated instant, SID: steamed instant; AC: Arabica coffee; Instant coffee blends: UID30/ AC: with a proportion of $30 \%$ of UID and $70 \%$ of AC, UID50/AC: with a proportion of $50 \%$ of UID and 50\% of AC, SID30/AC: with a proportion of $30 \%$ of SID and 70\% AC, SID50/AC: $50 \%$ SID and 50\% AC.

Since caffeine and CGA contents in instant coffee products were little affected by ST, and that PVA beans have high contents of these compounds (Franca; Mendonça; Oliveira, 2005; Ramalakshmi; Kubra; Rao, 2007), it can be said that the conditions proposed led a Robusta PVA instant coffee with a good profile of bioactive compounds.

Similar behavior (higher contents of CGA for the steamed product) was observed in blends with 30 and $50 \%$ of steamed and untreated instant Robusta PVA (Table 1). Arabica instant coffee presented lower content of caffeine

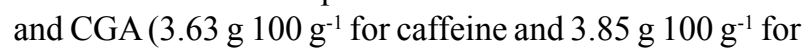
CGA) compared to Robusta SID and UID (Table 2). So, the addition of Arabica coffee, with characteristic lower content of these compounds (Vignoli; Bassoli; Benassi, 2011), reduced the contents in the blends. However, the profile of bioactive compounds in the blends was still quite 
expressive and similar to or higher than that described in the literature for instant coffees. The blends with steamed Robusta coffee were also highlighted by the higher content of CGA compared to untreated coffees.

\section{Sensory analysis of brews from instant coffee blends}

A good bioactive profile was observed for the instant coffee blends studied, however, it is necessary to evaluate the sensory impact of the presence of the Robusta defects on the corresponding coffee brews. It is worth noting that the large number of defects contained in the Robusta material used for the production of instant coffee of $75.3 \%$ (17.2\% black, $12.1 \%$ green; $20.8 \%$ sour and $25.2 \%$ other defects and impurities), was higher than to those described in the literature. Oliveira et al. (2006) reported $68.8 \%$ of defects $(3.2 \%$ black, $21.1 \%$ green, $40.5 \%$ sour and $4 \%$ others) for the Arabica coffee.

Triangular tests were performed in order to verify whether the ST could have an impact on the sensory perception of the presence of Robusta PVA, and in what proportion the difference would be perceived between blends with steamed and untreated coffee.

With the addition of $30 \%$ of steamed and untreated Robusta defect, no difference was observed between the blends UID30/AC and SID30/AC $(p=0.56)(13$ correct answers out of 39). It is possible to assure with $98 \%$ of confidence that below $22 \%$ of the assessors were able to distinguish the blends (lower than the defined $\mathrm{Pd}$ of 50\%) and that the products can be considered similar ( $99 \%$ of confidence).

The perception of difference between blends UID50/AC and SID50/AC ( $\mathrm{p}=0.04)$ occurred only with the addition of $50 \%$ of the steamed/untreated Robusta defect ( 19 correct answers out of 40 ). It is possible to assure with $98 \%$ of confidence that up to $44 \%$ of the assessors were able to distinguish the blends, and that the products can be considered different ( $95 \%$ of confidence).

This behavior agrees with that reported for roasted Robusta PVA coffee by Kalschne et al. (2018). The authors only observed sensory differences from control (a pure Arabic coffee) with the addition of $45 \%$ steamed Robusta PVA coffee in the blend.

Our results also suggest that, despite the recognized reduction in cup quality due to the defects, when the Robusta PVA is roasted separately and added to coffees with good cup quality, higher contents are needed to notice the presence of Robusta PVA. However, for steamed Robusta PVA coffee for which Kalschne et al. (2018) reported an improvement in the volatile profile in roasted coffee - it would probably be possible to use even a higher proportion in instant coffee blends compared to an untreated Robusta PVA.

Table 1: Caffeine and total chlorogenic acids content (g $100 \mathrm{~g}^{-1} \mathrm{dry}$ basis) of steamed and untreated Robusta PVA coffees: raw beans, roasted and instant coffees *

\begin{tabular}{cccc}
\hline \multirow{2}{*}{$\begin{array}{c}\text { Robusta } \\
\text { Bean/Coffee }\end{array}$} & Bioactive compounds & \multicolumn{2}{c}{ Treatment } \\
\cline { 3 - 4 } Raw & Caffeine & $1.34 \pm 0.00^{\mathrm{b}}$ & Untreated \\
\hline \multirow{2}{*}{ Roasted } & Chlorogenic acids & $4.49 \pm 0.21^{\mathrm{b}}$ & $5.04 \pm 0.02^{\mathrm{a}}$ \\
& Caffeine & $1.85 \pm 0.00^{\mathrm{a}}$ & $1.56 \pm 0.02^{\mathrm{b}}$ \\
\hline \multirow{2}{*}{ Instant } & Chlorogenic acids & $2.32 \pm 0.34^{\mathrm{a}}$ & $2.40 \pm 0.01^{\mathrm{a}}$ \\
\hline & Caffeine & $7.48 \pm 0.02^{\mathrm{a}}$ & $7.01 \pm 0.01^{\mathrm{b}}$ \\
& Chlorogenic acids & $6.44 \pm 0.19^{\mathrm{b}}$ & $8.74 \pm 0.08^{\mathrm{a}}$ \\
\hline
\end{tabular}

* Mean (duplicate) \pm standard deviation. Means with different letters in the same line show significant difference (t-test, $\mathrm{p} \leq 0.05)$.

Table 2: Caffeine and total chlorogenic acid contents ( $100 \mathrm{~g}^{-1} \mathrm{dry}$ basis) in the blended instant coffees*.

\begin{tabular}{cccc}
\hline \multirow{2}{*}{ Blends* } & Bioactive compounds & \multicolumn{2}{c}{ Treatment } \\
\cline { 3 - 4 } & Caffeine & Untreated & Untreated \\
\hline \multirow{2}{*}{$30 \%$} & Chlorogenic acids & $4.74 \pm 0.01$ & $4.69 \pm 0.02$ \\
& Caffeine & $4.75 \pm 0.01$ & $4.12 \pm 0.05$ \\
\multirow{2}{*}{$50 \%$} & Chlorogenic acids & $5.59 \pm 0.08$ & $5.53 \pm 0.01$ \\
& $5.51 \pm 0.24$ & $6.82 \pm 0.05$ \\
\hline
\end{tabular}

*Blends of instant Arabica coffee with 30 and $50 \%$ of Robusta SID and UID. Mean values (duplicate) \pm standard deviation. 
Blends UID50/AC and SID50/AC, for which a significant difference was observed, were compared regarding preference. In the paired preference test, SID50/AC was preferred by 24 out of 40 assessors ( $p$ $=0.13)$. It is possible to assure (90\% of confidence) that up to $40 \%$ of the assessors prefer the steamed PVA blend.

The acceptance of the preferred brew (SID50/AC) was evaluated and an average grade of $7.9 \pm 1.9$ (on a 10 -hedonic scale) was obtained. Stands out that $93.3 \%$ of acceptance (grades above 5) and only $6.7 \%$ of rejection (grades below 5) were observed, showing the feasibility of adding up to $50 \%$ of steamed Robusta PVA in a blend of Arabica coffee.

\section{CONCLUSIONS}

The use of steamed Robusta PVA coffee in the production of instant coffee is feasible under mild steam treatment conditions ( $2 \mathrm{bar} / 3 \mathrm{~min}$ ). It is possible to obtain an instant coffee to be used in blends with $50 \%$ Arabica coffee, with a good profile of bioactive compounds and well accepted.

\section{REFERENCES}

ABIC - Associação Brasileira da Indústria de Café. Tendências no consumo do café- Novembro 2014. 77p. Available in: <http://consorciopesquisacafe.com.br/arquivos/consorcio/ consumo/Tendencias_no_consumo_do_cafe_2014.pdf >. Access in: January, 03, 2020.

AMER, M. G.; MAZEN, N. F.; MOHAMED, A. M. Caffeine intake decreases oxidative stress and inflammatory biomarkers in experimental liver diseases induced by thioacetamide: biochemical and histological study. International Journal of Immunopathology and Pharmacology, 30(1):13-24, 2017.

BANDEIRA, R. D. C. C. et al. Composição volátil dos defeitos intrínsecos do café por CG/EM-headspace. Química Nova, 32(2):309-314, 2009.

BECKER, R.; SCHLABS, B.; WEISEMANN, C. Process for improving the quality of Robusta coffee. Patent US5019413. Date of publication: May, 28, 1991. Available in: <https://patents.google.com/patent/US5019413>. Access in: January, 03, 2020.

BEDOYA-RAMÍREZ, D. et al. Evaluation of the antioxidant capacity, furan compounds and cytoprotective/cytotoxic effects upon Caco-2 cells of commercial Colombian coffee. Food Chemistry, 219:364-372, 2017.
BEE, S. et al. The raw bean. In: ILLY, A.; VIANI, R. (Ed.). Espresso Coffee: The science of quality. 2. ed. London: Elsevier, 2005, p. 87-178.

CECAFÉ - Conselho de Exportadores de Café do Brasil. Relatório Mensal novembro 2019. Available in: <https://www.cecafe. com.br/publicacoes/relatorio-de-exportacoes/>. Accessed in: January, 03, 2020.

CORSO, M. P.; VIGNOLI, J. A.; BENASSI, M. T. Development of an instant coffee enriched with chlorogenic acids. Journal of Food Science and Technology, 53(3):1380-1388, 2016.

CRAIG, A. P. et al. Fourier transform infrared spectroscopy and near infrared spectroscopy for the quantification of defects in roasted coffees. Talanta, 134(1):379-386, 2015.

DAGLIA, M. et al. Antibacterial activity of coffee: Relationship between biological activity and chemical markers. Journal of Agriculture and Food Chemistry, 42(10):2273-2277, 1994.

DIAS, R. C. E.; BENASSI, M.T. Discrimination between arabica and robusta coffees using hydrosoluble compounds: Is the efficiency of the parameters dependent on the roast degree? Beverages, 1(3):127-139, 2015.

FRANCA, A. S.; MENDONÇA, J. C. F.; OLIVEIRA, S. D. Composition of green and roasted coffees of different cup qualities. LWT - Food Science and Technology, 38(7):709-715, 2005.

HEČIMOVIĆ, I. et al. Comparative study of polyphenols and caffeine in different coffee varieties affected by the degree of roasting. Food Chemistry, 129(3):991-1000, 2011.

KALSCHNE, D. L. et al. Steam pressure treatment of defective Coffea canephora beans improves the volatile profile and sensory acceptance of roasted coffee blends. Food Research International, 105:393-402, 2018.

KALSCHNE, D. L. et al. Effect of steam treatment on the profile of bioactive compounds and antioxidant activity of defective roasted coffee (Coffea canephora). LWT - Food Science and Technology, 99:364-370, 2019.

KITZBERGER, C. S. G. et al. Composição química de cafés árabica de cultivares tradicionais e modernas. Pesquisa Agropecuária Brasileira, 48(11):1498-1506, 2013.

KOBAYASHI, M. L; BENASSI, M. T. Caracterização sensorial de cafés solúveis comerciais por Perfil Flash. Semina: Ciências Agrárias, 33(2):3081-3092, 2012.

LINGLE, T. R; MENON, S. N. Cupping and grading: Discovering character and quality In: FOLMER, B. The Craft and Science of Coffee. London: Academic Press, 2017, p.181-204. 
MARCUCCI, C. T. et al. Teores de trigonelina, ácido 5-cafeoilquínico, cafeína e melanoidinas em cafés solúveis comerciais brasileiros. Química Nova, 36(4):544-548, 2013.

MARTINI, D. et al. Coffee consumption and oxidative stress: A review of human intervention studies. Molecules, 21 (8):1-20, 2016.

MORAES, P. C. B. T.; BOLINI, H. M. A. Different sweeteners in beverages prepared with instant and roasted ground coffee: Ideal and equivalent sweetness. Journal of Sensory Studies, 25(1):215-225, 2010.

NCBI - NATIONAL CENTER FOR BIOTECHNOLOGY INFORMATION. PubChem. Caffeine. 2019. Available in: <https://pubchem.ncbi.nlm.nih.gov/compound/Caffeine>. Access in: January, 03, 2020.

OLIVEIRA, L. S. et al. Proximate composition and fatty acids profile of green and roasted defective coffee beans. LWT - Food Science and Technology, 39(3):235-239, 2006.

OP \& P PRODUCT RESEARCH. V-Power. 2019. Available in: <http:// senstools.com/v-power.html>. Access in: January, 03, 2020.

PERRONE, D. et al. Comprehensive analysis of major and minor chlorogenic acids and lactones in economically relevant Brazilian coffee cultivars. Food Chemistry, 106(2):859867, 2008.

RAMALAKSHMI, K.; KUBRA, I. R.; RAO, L. J. M. Physicochemical characteristics of green coffee: Comparison of graded and defective beans. Journal of Food Science, 72(5): 333-337, 2007.

SOUZA, R. M. N.; BENASSI, M. T. Discrimination of commercial roasted and ground coffees according to chemical composition. Journal of the Brazilian Chemical Society, 23(7):1347-1354, 2012.

STATSOFT. STATISTICA for Windows: Computer program manual. Versão 7.1. Tulsa: Software Inc., 2006.

TOCI, A. T.; FARAH, A. Volatile fingerprint of Brazilian defective coffee seeds: corroboration of potential marker compounds and identification of new low quality indicators. Food Chemistry, 153:298-314, 2014.

VARSÁNYI, M. et al. Process for improving the flavour of robusta coffee sorts. Patent EP0282345 A2. Date of publication: March, 11, 1988. Available in: <https://patents. google.com/patent/EP0282345A2/en>. Access in: January, 03, 2020.

VIGNOLI, J. A.; BASSOLI, D. G.; BENASSI, M. T. Antioxidant activity, polyphenols, caffeine and melanoidins in soluble coffee: The influence of processing conditions and raw material. Food Chemistry, 124(2):863-868, 2011.

Villanueva, N. D. M.; PetenAte, A. J.; Silva, M. A. A. P. Performance of the hybrid hedonic scale as compared to the traditional hedonic, self-adjusting and ranking scales. Food Quality and Preference, 16(8):691-703, 2005.

WONGSA, P. et al. Quality and bioactive compounds of blends of Arabica and Robusta spray-dried coffee. Food Chemistry, 283(6):579-587, 2019.

YOSHINARI, O.; IGARASHI, K. Antidiabetic effects of trigonelline: Comparison with nicotinic acid. In: PREEDY, V. R. Coffee in health and disease prevention, 1. ed. London: Elsevier. 2015. p. 765-775. 